\title{
FUNCTIONAL AND OPERATIONAL STRUCTURES OF THE MOTORWAY TELEMATICS SYSTEM
}

\section{STRUKTURY FUNKCJONALNO-EKSPLOATACYJNE SYSTEMU TELEMATYKI AUTOSTRADOWEJ}

\author{
Wojciech Wawrzyński ${ }^{1}$, Mirosław Siergiejczyk ${ }^{2}$ \\ (1) Warsaw University of Technology, Faculty of Transport \\ Politechnika Warszawska Wydzial Transportu \\ 00-662 Warszawa Koszykowa 75 \\ (2) Warsaw University of Technology, Faculty of Transport \\ Politechnika Warszawska Wydzial Transportu \\ 00-662 Warszawa Koszykowa 75 \\ e-mail: wwa@it.pw.edu.pl, msi@it.pw.edu.pl
}

\begin{abstract}
The paper presents the issues relating to the identification of functional and operational structures of the motorway telematics system. General functional structure of the motorway telematics system has been presented, as well as its components used for transmission, transfer and reception of information. Then, the information flow process has been shown for a selected group of telematics services during the tolling process.
\end{abstract}

Keywords: telematics, transport, information flow, structure.

Streszczenie: W referacie przedstawione zostały zagadnia identyfikacji struktur funkcjonalnych i eksploatacyjnych systemu telematyki autostradowej. Przedstawiona została ogólna struktura funkcjonalna sytemu telematyki autostradowej z uwzględnieniem elementów realizujących funkcje nadawania, przesyłania i odbioru informacji. Następnie dla wybranej grupy usług telematycznych został przestawiony proces przepływu informacji w czasie eksploatacji systemów pobierania opłat.

Slowa kluczowe: telematyka, transport, przepływ informacji, struktura. 


\section{FUNCTIONAL AND OPERATIONAL STRUCTURES OF THE MOTORWAY TELEMATICS SYSTEM}

\section{Introduction}

The transport telematics issues appeared in Polish literature as early as mid 1990 's, when an attempt was made to specify the scope and of the area of application of the term "transport telematics" [4], which has been defined as a domain of knowledge and technical activity integrating the computer science with telecommunication for the requirements of the transport systems.

Transport telematics is knowledge on the transport which integrates the computer science and telecommunication for application in the management and control of the traffic in transport systems, stimulates the technical and organizational activities for increased effectiveness and safety during the operation of such systems [3].

Individual telematics solutions cooperating with each other, often under supervision of a master factor (i.e. a man supported by specialized applications) make up the Intelligent Transport System (ITS).

The key function of the telematics systems is the use of information, i.e. its obtaining, processing, distribution including the transmission and utilization in the decision-making processes. Such processes include the imposed, determined processes (such as automatic traffic control) as well as the evenrelated processes (decisions of the dispatchers, administrators, independent infrastructure users such as drivers or pedestrians, etc., supported by current information [6].

An advanced solution of the transport telematics is the intelligent transport. In the widest sense, it is the transport supported to a high degree by integrated solutions in terms of measurement (sensors, detectors), IT and information, as well as automation. The transport telematics includes dedicated measurement, telecommunication, IT and information systems, particularly the equipment (with software) and the services performed by this equipment. The equipment, and the services performed with it, is designed in the form of so-called telematics applications that is the tools fulfilling given tasks. Intelligent transport integrates all types and means of transport, infrastructure, organizations and companies, and the maintenance 
and management processes. The telematics solutions uses in the intelligent transport provide also the connections between the components, ensure cooperation between them and with the environment, particularly with the users. The telematics solutions can be adapted to a separated transport type (i.e. road transport) and cover a selected geographical area (i.e. an administrative division in a country), but also can integrate a continental or even global transport system. Such solutions usually have open architecture and are scalable: they can be expanded, supplements and modernized if necessary. Their task is to ensure such a degree of cooperation between individual system components and interaction with the users that will ensure increased travel and transport safety, increased transport reliability, better infrastructure utilization, better economic performance, and reduction in the environment degradation.

\section{Functional structure of the motorway telematics system}

The most essential thing in the intelligent transport system is the amount and diversity of the information which is incoming and processed in the system, and also the number of areas of activities realized by the system as a whole.

As we have already mentioned, the basic property of the telematics applications is their ability to supply and process an abundant sent of the information adequate to a given use and adapted to the needs of the recipients - users of such information which is assigned to a given time and place. The information operations can take place automatically or interactively - on request of a user. An important feature of the telematics applications is their capability of effective harmonization and coordination of the operations of various subsystems.

A special emphasis is placed on the motorway telematics system (fig. 1). This is for a number of reasons, Firstly, it has been decided that the development of road transport in general and of motorway transport in particular is a priority in Poland. The traffic density on main roads has reached such levels that without intensification of the motorway construction and reconstruction programme the country can be paralysed. Consequently, the scientists should focus on the motorway transport issues. Secondly, a motorway without a necessary telematics equipment adapted to the needs imposed by existing and expected traffic parameters and to the needs related to its geographical route, existing hazards and many other factors, does not meet the requirements of the users and operators and the use of such solution is both unsafe and economically ineffective. 


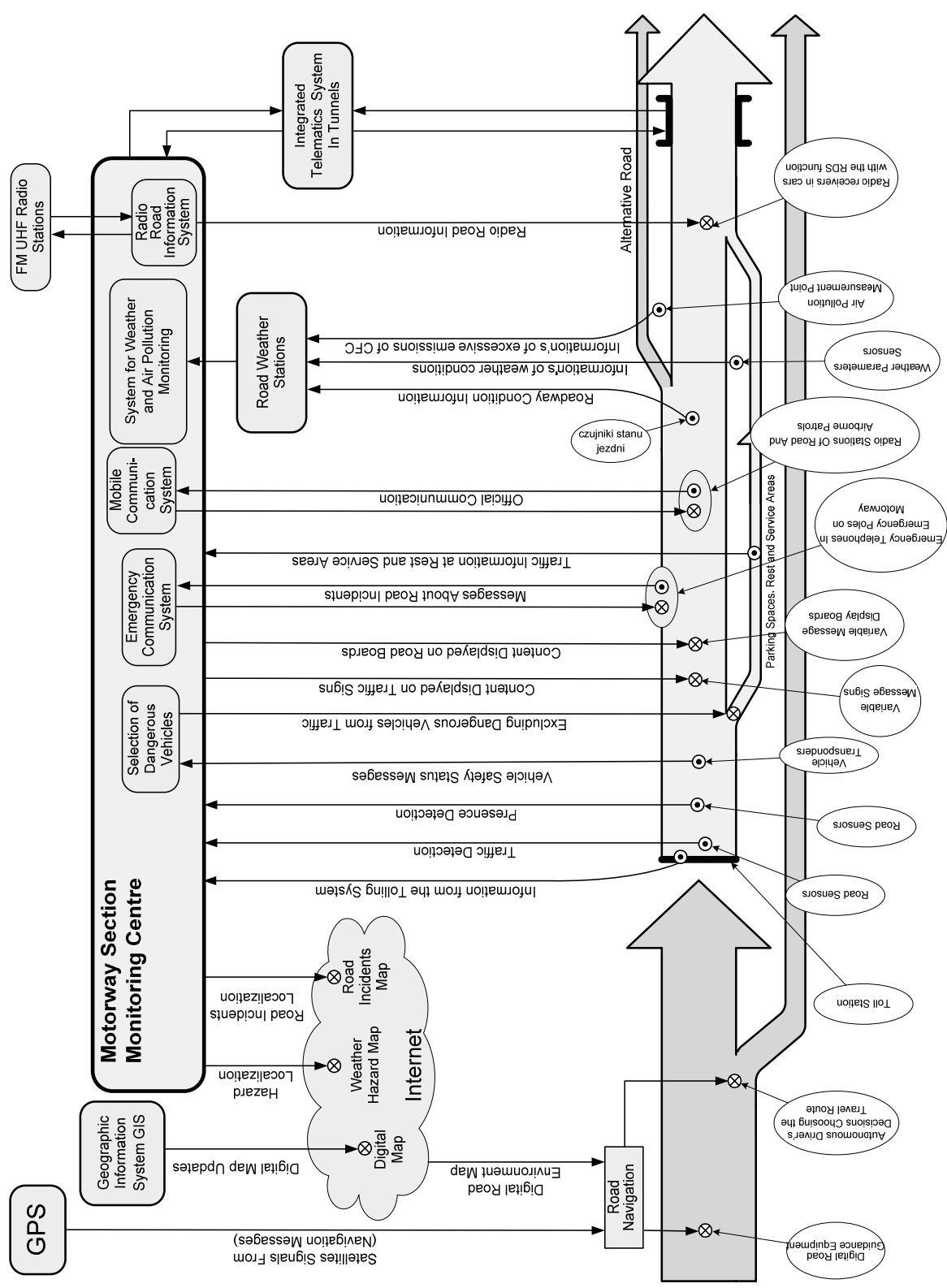

Fig. 1. Functional and operational structure of the motorway telematics system; $\odot$ sensors, $\otimes$ - activators

Thirdly, the motorway telematics systems and the services they provide include so many areas and solutions that one can say that they are representative of many other solutions in other types of transport. 
The motorway telematics system includes many dedicated subsystems, performing given operational functions. Such (sub)systems can be divided as follows:

- system generating a digital environment map, allowing ten drivers to choose the travel route,

- tolling system,

- traffic and roadway occupation detection system,

- traffic safety control system, including the selection of dangerous vehicles,

- system controlling the variable message signs and display boards,

- traffic control system at rest and service areas,

- emergency communication system,

- mobile communication system,

- system for weather and air pollution monitoring,

- radio road information system,

- integrated transport telematics system in tunnels.

The tasks performed by given subsystems comprise a whole representing a correct traffic surveillance system, traffic control system, road incidents management, road maintenance and performing other activities useful for a suitable operation of a motorway [5].

\section{Operational structure of the electronic tolling system}

\subsection{Introduction}

The essence of the transport telematics systems is the provisioning of services for various groups of users, directly or indirectly related to the movement of people and/or cargo. The recipients of the services can be individual users of the transport systems (travellers), infrastructure operators, maintenance personnel, carriage planning operators and other transport-related recipient groups. For these users 32 telematics systems services have been defined, divided into eight functional groups by their specific character. The division is partially based (29 services) on the national plan of intelligent transportation systems in the USA [2], also presented in other publications [1].

The division into functional groups is to some extent relative. Such services can be grouped so that they can be arranged according to a few various methods depending on the priorities and needs of a given transport solution in a region. In addition, individual services represent varying technical 
infrastructure necessary for their implementation and hence can have the common elements with other types of proposed solutions.

One of the important criteria of division into the groups is the selection of services with a possibility of internal integration, because implementation of many of them requires a mutual exchange of information. Such necessary internal exchange of information requires that the services be arranged in an integrated system which is the group. Then, good utility parameters of the system can be achieved.

\subsection{Service group relating to the electronic tolling}

This group comprises only one transport telematics service, known as the electronic payment service. The main task of this service is to introduce a common toll payment system for travellers. The information flow between the telematics equipment performing the toll payment function is presented in figure 2.

The electronic payment service has the four major components:

- Set of toll stations. Such stations provide to the drivers an opportunity to pay the toll without the need to stop or slow down their vehicles, and consequently do not cause a waste of time and do not increase the air pollution. The toll collection systems can collect the payments depending on the vehicle type, can compare the payment made with the actual distance covered by the vehicle, and can inform the driver about the current payment status on a display in the cockpit. If the system detects an incorrect payment, it automatically sends information to relevant management centres.

- Set of motorway toll payment methods. Using various methods is a way of adapting the payment to the preferences of individual drivers or transport companies. Various payment forms can be implemented, in terms of the method and transaction safety. It will help the transport centres operators plan the routes for individual vehicles.

- Electronic parking systems. These systems make possible for the drivers to make the payment with cards or special tags.

- Integrated electronic payment systems. The final goal of the electronic payment should be to combine all above-mentioned components and create a single payment system for all transport services. With this integrated system, the travellers could use the same equipment to pay the toll, parking fees, and other charges for using the transport systems. 


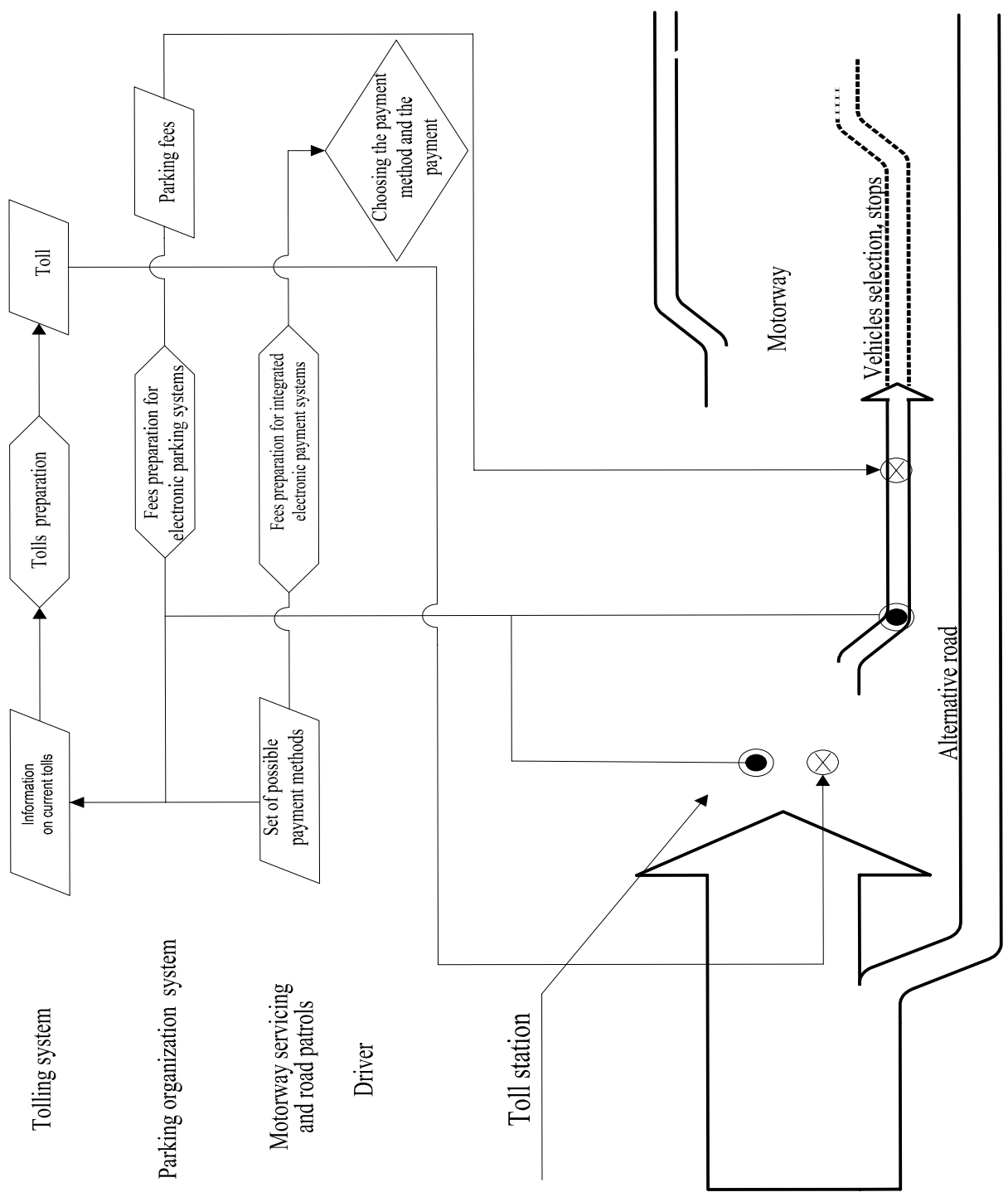

Fig. 2. Information flow between the telematics equipment performing the toll payment function

\section{Summary}

Quality of transport telematics services depends on the network integrity, understood as the independence of an offered service from proposed access method and the type of transmission protocol. Regardless which method is used to transmit information to the user, the provided service must have identical parameters. The quality level of a telematics service should be the 
same any time, any place, irrespective whether the suer is at home, at work or is travelling. This leads to the need to create and analyse the functional and operational structures in the context of the availability and continuity of telematics services in the transport sector.

\section{Literature}

1. Chowdhury M. A., Sadek A.: Fundamentals of Intelligent Transportation Systems Planning. Artech House ITS Library. Boston, London 2003 Klein L.A.: Sensor Technologies and date requirements if ITS. Artech House, ITS Library, 2001.

2. U.S. Department of Transportation, Federal Highway Administration, The National Intelligent Transportation Systems Program Plan, Washington D.C., 1995

3. Wawrzyński W.: Telematyka transportu - zakres pojęciowy i obszar zastosowań, Przegląd Komunikacyjny nr 11, Warszawa 1997

4. Wawrzyński W.: Miejsce telematyki w dyscyplinie naukowej transport. Maszynopis. Wydział Transportu PW, Warszawa 2003.

5. Wawrzyński W., Siergiejczyk M. i inni: Metody wykorzystania środków telematyki we wspomaganiu realizacji zadan transportowych. (Methods of usage of telematics means in supporting fulfilment of transport tasks). Report from KBN grant 5T12C 066 25. Warsaw 2006.

6. Wydro K.: Telematyka- znaczenia $i$ definicje terminu. (Telematics meainings and definitions of the term). Telekomunikacja i Techniki Informacyjne. Wyd. Instytut Łączności, Warszawa 2005. 


\section{STRUKTURY FUNKCJONALNO-EKSPLOATACYJNE SYSTEMU TELEMATYKI AUTOSTRADOWEJ}

\section{Wstęp}

Problematyka telematyki transportu pojawiła się w polskich publikacjach $\mathrm{w}$ połowie lat dziewięćdziesiątych. Już wtedy podjęto próby określenia zakresu pojęciowego i obszaru zastosowań telematyki transportu [4], którą zdefiniowano jako dziedzinę wiedzy i działalności technicznej integrującej informatykę $\mathrm{z}$ telekomunikacją $\mathrm{w}$ zastosowaniu do potrzeb systemów transportowych.

Telematyka transportu jest to dział wiedzy o transporcie integrujący informatykę i telekomunikację $\mathrm{w}$ zastosowaniach dla potrzeb zarządzania i sterowania ruchem w systemach transportowych, stymulujący działalność techniczno - organizacyjną umożliwiającą podniesienie efektywności i bezpieczeństwa eksploatacji tych systemów [3].

Poszczególne rozwiązania telematyczne współpracujące ze sobą, często pod kontrolą czynnika nadrzędnego (np. człowieka wspieranego przez odpowiednie, wyspecjalizowane aplikacje), tworzą Inteligentne Systemy Transportowe (ITS - Intelligent Transport System).

Kluczowymi funkcjami systemów telematycznych są funkcje operowania informacja. Chodzi tu o jej pozyskiwanie, przetwarzanie, dystrybucję wraz $\mathrm{z}$ transmisją i wykorzystaniem $\mathrm{w}$ procesach decyzyjnych. Procesy takie, to zarówno procesy realizowane $\mathrm{W}$ sposób $\mathrm{z}$ góry zdeterminowany (np. automatyczne sterowanie ruchem) lub procesy wynikające z sytuacji doraźnych (decyzje dysponentów, dyspozytorów, niezależnych użytkowników infrastruktury takich jak kierowcy czy piesi itp., wspomagane bieżącą informacją) [6].

Zaawansowanym rozwiązaniem telematyki transportu jest inteligentny transport. W najszerszym ujęciu jest to transport wsparty w wysokim stopniu zintegrowanymi rozwiązaniami pomiarowymi (czujniki, sensory), telekomunikacyjnymi, informatycznymi i informacyjnymi, a także automatycznymi. Część stanowiąca dedykowane pomiarowe, telekomunikacyjne, informatyczne i informacyjne systemy, w szczególności wyposażenie (wraz z oprogramowaniem) i usługi przez to wyposażenie realizowane obejmuje telematyka transportu. Wyposażenie to, oraz 
realizowane za ich pomocą usługi, są konstruowane w formie tzw. aplikacji telematycznych, tj. narzędzi realizujących konkretne zadania. Inteligentny transport integruje wszystkie rodzaje i środki transportu, infrastruktury, organizacje i przedsiębiorstwa oraz procesy utrzymania i zarządzania. Stosowane $\mathrm{w}$ nim rozwiązania telematyczne zapewniają także połączenia między tymi elementami, ich współpracę, a także współdziałania z otoczeniem, w tym, z użytkownikami w szczególności. Rozwiązania telematyczne mogą dostosowane do wyodrębnionego rodzaju transportu (np. transportu drogowego) i obejmować wybrany obszar geograficzny (np. jednostkę administracyjną kraju), ale też mogą integrować i koordynować kontynentalny czy zgoła globalny system transportu. Rozwiązania takie mają zazwyczaj otwartą architekturę i są skalowalne: w miarę potrzeb mogą być rozbudowywane, uzupełniane i modernizowane. Ich celem jest zapewnienie takiego współdziałania poszczególnych elementów systemu i takiej interakcji z użytkownikami, które zapewniać będzie zwiększenie bezpieczeństwa podróży i przewozów, zwiększenie niezawodności transportu, lepsze wykorzystanie infrastruktury i uzyskiwanie lepszych wyników ekonomicznych, a także ograniczenie degradacji środowiska.

\section{Struktura funkcjonalna systemu telematyki autostradowej}

W systemie inteligentnego transportu istotna jest w pierwszym rzędzie ilość i różnorodność informacji przepływających i przetwarzanych w systemie oraz liczność dziedzin aktywności realizowanych przez system jako całość. Jak wspomniano podstawową właściwością aplikacji telematycznych jest możliwość dostarczania i przetwarzania bogatego zbioru informacji adekwatnych dla danego zastosowania, dostosowanych do potrzeb odbiorców - użytkowników tych informacji, przynależnych do właściwych miejsc i właściwego czasu. Operacje informacyjne mogą być realizowane bądź to w sposób automatyczny, bądź interaktywnie, na konkretne żądanie użytkownika. Ważną cechą aplikacji telematycznych jest zdolność efektywnego kojarzenia działania różnych podsystemów i wprowadzania ich w skoordynowany tryb funkcjonowania.

Przedmiotem szczególnego zainteresowania $\mathrm{w}$ jest system telematyki autostradowej (rys.1). Wynika to z różnych względów. Po pierwsze uznano, że w obecnie rozwój transportu drogowego a szczególnie autostradowego w Polsce jest problemem priorytetowym. Gęstość ruchu bowiem na drogach krajowych osiagnęła takie rozmiary, że bez intensywnych działań w kierunku budowy i rozbudowy autostrad grozi krajowi paraliż 
komunikacyjny. Zatem problematyka transportu autostradowego winna być w centrum zainteresowania naukowców.

Po drugie autostrada bez należytego wyposażenia telematycznego dostosowanego do potrzeb wynikających ze spodziewanych i istniejących parametrów ruchu i dostosowanego do potrzeb wynikających z jej przebiegu terytorialnego, istniejących zagrożeń i wielu innych czynników, nie spełnia oczekiwań użytkowników i eksploatatorów powodując, że użytkowanie takiego rozwiązania jest i niebezpieczne i mało efektywne ekonomicznie.

Po trzecie wszakże systemy telematyki autostradowej i usługi które one realizują obejmują tak wiele dziedzin techniki i rozwiązań użytkowych, że można zaryzykować twierdzenie o ich reprezentatywności wobec wielu innych rozwiązań w innych rodzajach transportu.

System telematyki autostradowej obejmuje wiele systemów składowych dedykowanych do wykonywania poszczególnych funkcji eksploatacyjnych. Systemy te można określić jak poniżej:

- system generowania cyfrowej mapy środowiskowej umożliwiającej kierowcom podjęcie decyzji o wyborze trasy podróżowania,

- System poboru opłat,

- system detekcji ruchu i zajętości jezdni,

- system nadzoru bezpieczeństwa ruchu wraz z selekcją pojazdów niebezpiecznych,

- system sterowania znakami o zmiennej treści i tablicami informacyjnymi,

- system dozorowania ruchu w Miejscach Obsługi Podróżnych,

- system łączności awaryjnej,

- system łączności ruchomej,

- system monitorowania warunków pogodowych i zanieczyszczeń powietrza,

- system radiowej informacji drogowej,

- zintegrowany system telematyki transportu w tunelach.

Zadania wykonywane przez poszczególne podsystemy składają się na całość reprezentującą właściwy system dozorowania ruchem, sterowania ruchem, predykcji sytuacji niebezpiecznych, zarządzania zdarzeniami drogowymi, utrzymania drogi i realizujący inne czynności przydatne we właściwej eksploatacji autostrady [5]. 


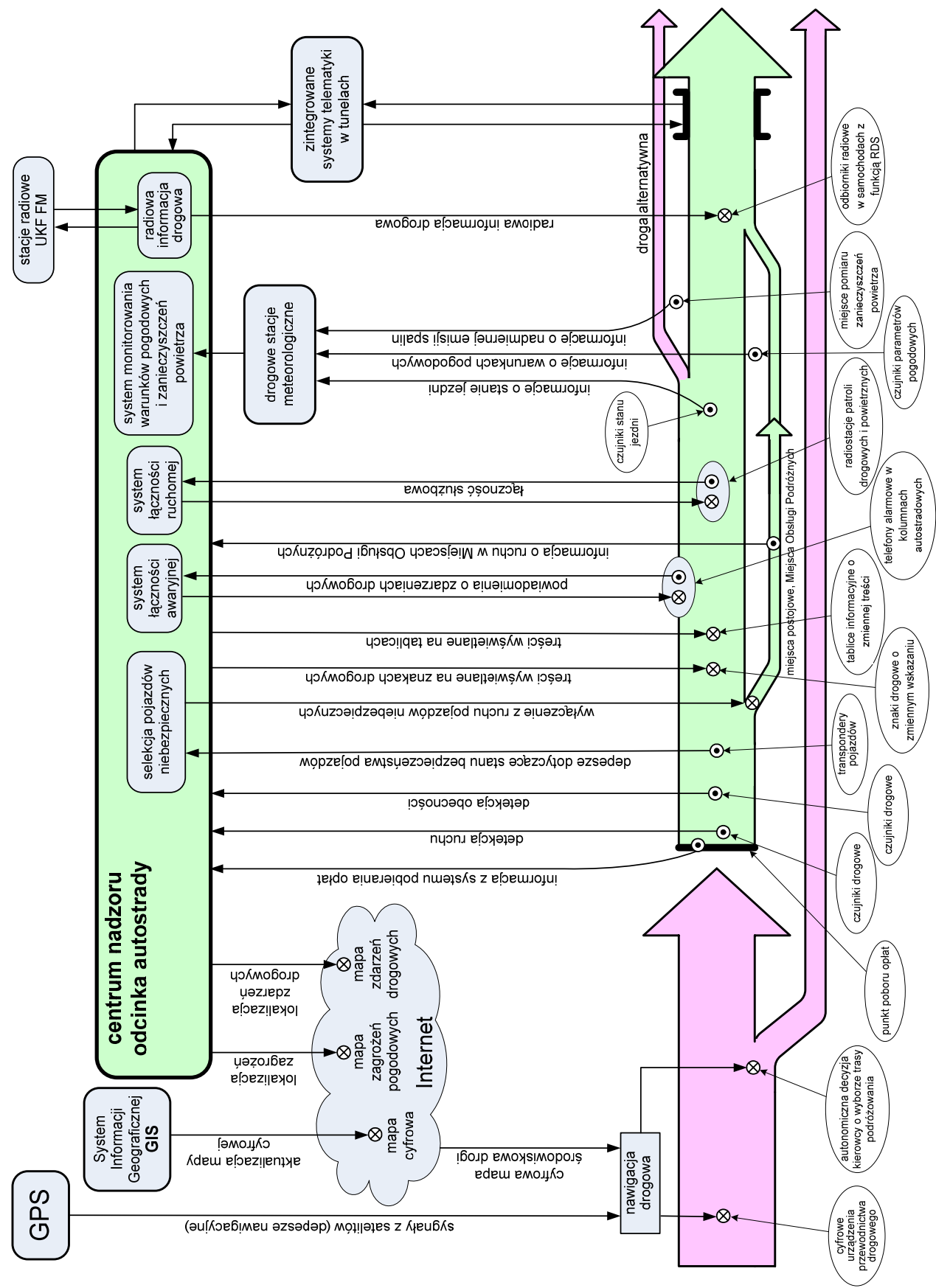

Rys. 1.Struktura funkcjonalno eksploatacyjna systemu telematyki autostradowej; $\odot$ - sensory, $\otimes$ - aktywatory 
Struktury funkcjonalno-eksploatacyjne systemu.....

\section{Struktura eksploatacyjna realizacji usługi elektronicznego pobierania opłat}

\subsection{Wprowadzenie}

Istotą funkcjonowania systemów telematyki transportu jest realizacja usług przeznaczonych dla różnych grup odbiorców związanych bezpośrednio lub pośrednio $\mathrm{z}$ realizowanymi procesami przemieszczania ludzi i/lub ładunków. Odbiorcami usług mogą być indywidualni użytkownicy systemów transportowych (podróżnymi), operatorzy infrastruktury, personel służb utrzymania, operatorzy planujący przewozy i inne grupy odbiorców związanych $\mathrm{z}$ transportem. Dla tych odbiorców zdefiniowano 32 usługi systemów telematycznych pogrupowane $\mathrm{w}$ osiem grup funkcjonalnych charakteryzujących ich specyfikę. Podział ten oparty jest częściowo (29 usług) na państwowym planie programu inteligentnych systemów transportowych w USA [2] prezentowanym też w innych publikacjach [1]. Podział na grupy funkcjonalne zachowuje charakter pewnej względności. Usługi te moga być łączone tak by mogły być rozmieszczone na kilka różnych sposobów $\mathrm{w}$ zależności od priorytetów i potrzeb danego rozwiązania transportowego $\mathrm{w}$ regionie. Ponadto poszczególne usługi reprezentują sobą różne zaplecze techniczne niezbędne do ich realizacji i przez to mogą posiadać elementy wspólne $\mathrm{z}$ innymi rodzajami proponowanych rozwiązań.

Jednym $\mathrm{z}$ istotnych kryteriów podziału na grupy jest dobór usług mających możliwość wewnętrznej integracji, gdyż realizacja wielu z nich wymaga dokonania wymiany informacji pomiędzy sobą. Ta konieczna wewnętrzna wymiana informacji wymaga rozmieszczeniem usług w zintegrowanym systemie jaki stanowi grupa. Dzięki temu można osiągnąć dobre parametry użytkowe systemu.

\subsection{Grupa uslug zwiqzana z elektronicznym systemem poboru oplat}

Grupa ta składa się tylko z jednej usługi telematyki transportu znanej pod nazwą usługi płatności elektronicznej (electronic payment services). Głównym celem tej usługi jest wprowadzenie podróżnym wspólnego sposobu realizacji płatności za korzystanie $\mathrm{z}$ dróg. $\mathrm{Na}$ rysunku 2 przedstawiono przepływ informacji pomiędzy urządzeniami telematyki realizującymi usługę elektronicznego systemu poboru opłat. 


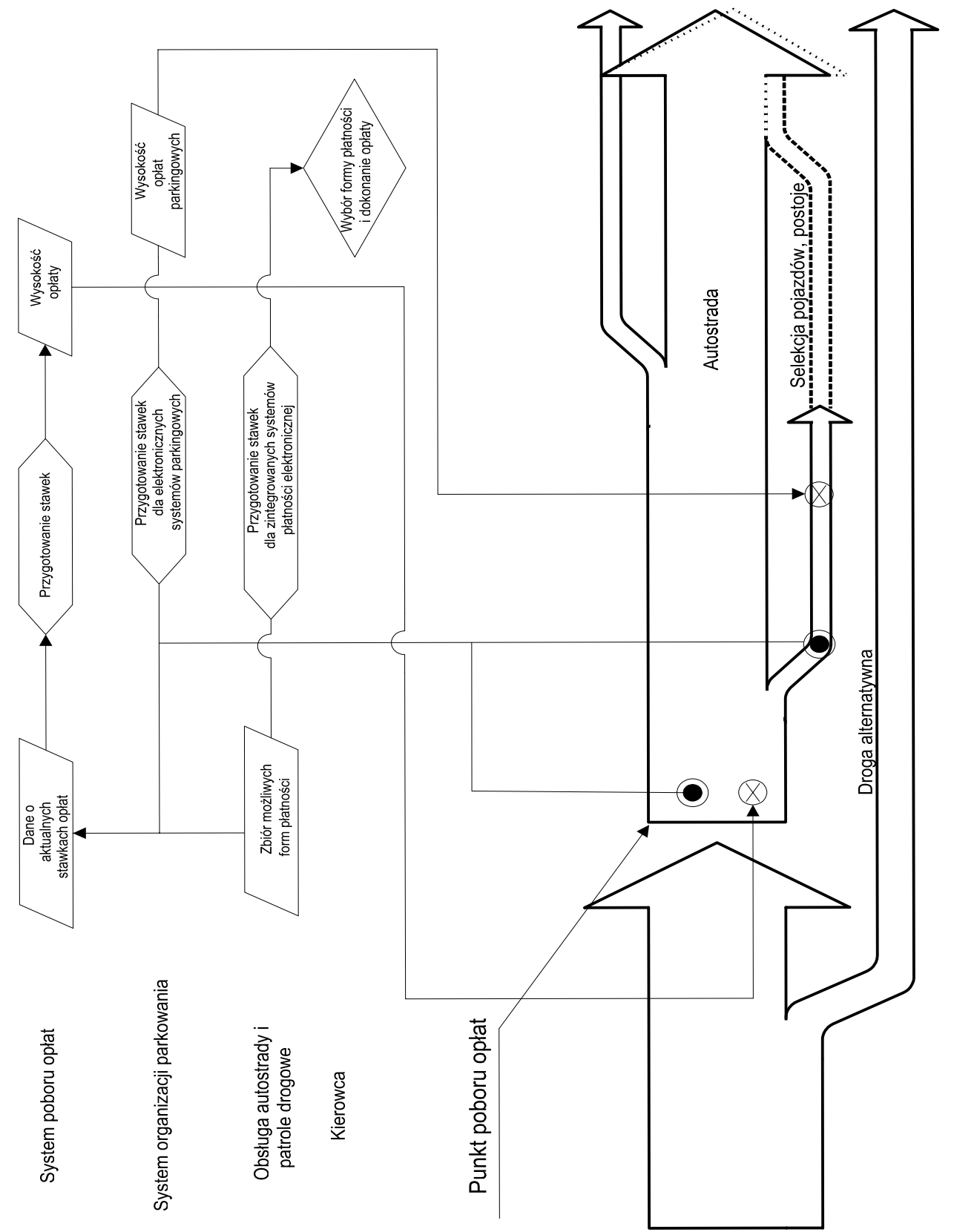

Rys. 2. Przepływ informacji pomiędzy urządzeniami telematyki realizującymi usługę elektronicznego systemu poboru opłat 
Struktury funkcjonalno-eksploatacyjne systemu.....

Usługa płatności elektronicznej składa się $\mathrm{z}$ czterech głównych komponentów:

- Zbiór punktów poboru opłat. Punkty te umożliwiają kierowcom opłacenie należności bez konieczności zatrzymania lub zwalniania a tym samym tym samym nie powodują strat czas, jak również zwiększania zanieczyszczeń powietrza. Systemy poboru myta mają możliwość pobierania opłat $\mathrm{W}$ zależności od rodzaju pojazdu, porównania wniesionej opłaty za przejazd $\mathrm{z}$ faktyczną odległością pokonaną przez pojazd oraz informowania kierowcy o aktualnym stanie opłat na zainstalowanym wewnątrz pojazdu wyświetlaczu. W przypadku stwierdzenia niewłaściwej realizacji opłaty automatycznie wysyłają informację o tym fakcie do odpowiednich centrów zarządzających.

- Zbiór form płatności za przejazd płatnym odcinkiem autostrady. Stosowanie różnych form płatności umożliwiają dostosowanie przekazywania opłat do preferencji kierowców czy firm transportowych. Umożliwia to wprowadzenie w życie różnych form płatności $\mathrm{z}$ uwagi na sposób ich realizacji i bezpieczeństwo transakcji. Pomagają to operatorom centrów transportowych planowanie trasy przejazdu poszczególnych pojazdów.

- Elektroniczne systemy parkingowe. Systemy te umożliwiają kierowcom opłacanie należności przy pomocy kart lub odpowiednich tagów.

- Zintegrowane systemy płatności elektronicznej. Ostatecznym celem rozwoju usługi płatności elektronicznej łączenie wszystkich poprzednio wymienionych komponentów, aby umożliwić wprowadzenie jednego systemu płatności, który zostanie przyjęty dla wszystkich usług transportowych. Z użyciem zintegrowanego systemu płatności podróżni będący $w$ drodze mógłby opłacać przy pomocy tych samych urządzeń płatności za parkowanie, myto i inne opłaty wynikające $\mathrm{z}$ potrzeb użytkowania systemów transportowych.

\section{Posumowanie}

Jakość usług telematycznych w transporcie jest zależna od integralności sieci, rozumianej jako niezależność oferowanej usługi od zastosowanej metody dostępu i od rodzaju protokołu przesyłania. Niezależnie od tego, jaki sposób jest wykorzystany do przesłania informacji do użytkownika, 
dostarczana usługa musi się charakteryzować tymi samymi parametrami. Poziom jakości usługi telematycznej powinien być taki sam w każdym miejscu, niezależnie od tego, czy użytkownik znajduje się w domu, w miejscu pracy czy, a zwłaszcza w ruchu - podróży. Prowadzi to do potrzeby tworzenia i analizowania struktur funkcjonalno-eksploatacyjnych w aspekcie dostępności i ciągłości świadczenia usług telematycznych w transporcie.

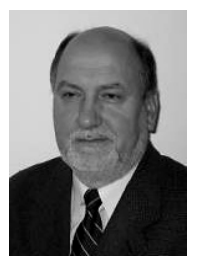

Prof. dr hab. inż. Wojciech Wawrzyński, Warsaw University of Technology Faculty of Transport Division of Transport Telecommunication,. Professor, specialization: exploitation, diagnostics and safety of transport system, telematics of transport systems. Several publication in field.

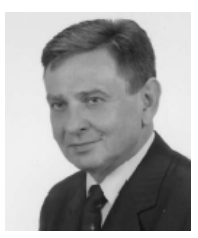

Dr inż. Mirosław Siergiejczyk, Warsaw University of Technology Faculty of Transport Division of Transport Telecommunication,. Assistant Professor, specialization: telecommunications system, reliability and exploitation of telematics transport systems. Several publication in field. 